\title{
A REVIEW NOVEL CORONAVIRUS
}

\author{
KONDAPURAM PARAMESHWAR ${ }^{1,2 *}$, SAGAR PAMU ${ }^{1,3}$, KOSIKA SANDEEP $^{1}$, CHINDAM SURESH ${ }^{1}$
}

${ }^{1}$ School of pharmacy, Gurunanak Institute of Technical Campus, Hyderabad, Telangana, India. ${ }^{2}$ Department of Pharmacy, Gandhi Institute of Technology and Management University, Vizag, Andhra Pradesh, India. ${ }^{3}$ School of Pharmaceutical Sciences, Lovely Professional University, Jalandhar, Punjab, India. Email: parameshwarkp@gmail.com

Received: 20 January 2020, Revised and Accepted: 28 February 2020

\begin{abstract}
Coronaviruses (CoVs), incorporated positive-sense RNA diseases, are depicted by the club-like spikes that adventure from their surface, an abnormally huge RNA genome, and a specific replication technique. CoVs cause a selection of diseases in mammals and birds ranging from enteritis in cows and pigs and upper respiratory sickness in chickens too possibly deadly human respiratory diseases. Here, we provide a quick presentation to CoVs talking about their replication and pathogenicity, and current avoidance and treatment techniques. We likewise mention the episodes of the profoundly pathogenic severe acute respiratory syndrome CoV (SARS-CoV) and thus the recently identify Middle Eastern respiratory syndrome CoV (MERS-CoV).
\end{abstract}

Keywords: Coronaviruses, Positive-sense RNA infections, Respiratory syndrome.

(C) 2020 The Authors. Published by Innovare Academic Sciences Pvt Ltd. This is an open access article under the CC BY license (http://creativecommons. org/licenses/by/4. 0/) DOI: http://dx.doi.org/10.22159/ajpcr.2020.v13i4.36982

\section{INTRODUCTION}

Coronaviruses (CoVs) were first recognized during the 1960s, however, we do not have the foggiest idea where they originate from. A CoV may be a kind of regular infection that causes a disease in your nose, sinuses, or upper throat [1]. Most CoVs are not perilous. They get their name from their crownlike shape. Here and there, however not frequently, a CoVs can taint the two creatures and people [2]. Most CoVs spread a uniform way other cold-causing infections do: Through contaminated individuals hacking and wheezing, by contacting a tainted individual' s hand or face, or by contacting things, as an example, door handles that tainted individuals have contacted [3]. The side effects of most CoVs are such as other upper respiratory contamination, including runny nose, hacking, pharyngitis, and here and there a fever. Much of the time, you will not know whether you've got a carnivorous or an alternate cold-causing infection, for instance, rhinovirus. Including nose and throat societies and blood work, to ascertain if your virus was caused by a CoV, yet there is no motivation to. The test outcomes would not change how you treat your side effects, which commonly leave during few days [4]. Be that because it may, if a carnivorous contamination spreads to the lower tract (your windpipe and your lungs), it can cause pneumonia, particularly. In additional seasoned individuals, individuals with coronary illness, or individuals with debilitated safe frameworks [5].

\section{SYMPTOMS OF CORONAVIRUS}

Fever

Fever is the point at which a human internal heat level goes over the ordinary scope of $36-37^{\circ} \mathrm{C}\left(98-100^{\circ}\right.$ Fahrenheit). It is a typical restorative sign. Different expressions for a fever incorporate precise and controlled hyperthermia. As the internal heat level goes up, the individual may feel cold until it levels off and quits rising [11].

\section{Chest pain}

Heart or vein issues that can cause chest torment: Angina or a respiratory failure. The most well-known manifestation is chest torment that may feel such as snugness, substantial weight, pressing, or pulverizing torment [12]. Expanding (irritation) in the sac that encompasses the heart causes torment in the middle piece of the chest.

\section{Chills}

The sentiment of being cold, however, not really in a cool domain, regularly joined by soldering or shaking $[13,14]$.

\section{Rapid heat beat}

There is no antibody for CoV. To help forestall a coronavirus disease, do very similar things you do to maintain a strategic distance from the normal virus [15]

\section{Breathing difficulties}

There are numerous reasons for breathing issues. These regular breathing issues incorporate constant sinusitis, hypersensitivities, and asthma. These issues can cause a large group of side effects [16], for example, nasal blockage, runny nose, irritated or watery eyes, chest clog, hack, wheezing, and worked relaxing.

\section{Pneumonia}

Pneumonia is a disease of the lungs with a scope of potential causes. It tends to be a genuine and dangerous illness. It ordinarily begins with a bacterial, viral, or parasitic disease. The lungs become aroused, and the small air sacs, or alveoli, inside the lungs top off with liquid $[17,18]$.

There is no antibody for coronavirus. To help forestall a coronavirus disease, do very similar things you do to maintain a strategic distance from the normal virus [19-22]:

- Wash your hands completely with cleanser and warm water or with a liquor based hand sanitizer

- Keep your hands and fingers from your eyes, nose, and mouth

- Avoid close contact with individuals who are contaminated

- You treat a coronavirus contamination a similar way you treat a virus:

- Get a lot of rest

- Drink liquids

- Take over-the-counter medication for an irritated throat and fever. However, do not offer headache medicine to youngsters or teenagers more youthful than use ibuprofen or acetaminophen

- A humidifier or hot shower can likewise help facilitate a sore and scratchy throat

- Even when a coronavirus causes Middle Eastern respiratory syndrome (MERS) or severe acute respiratory syndrome (SARS) in different nations, the sort of coronavirus contamination normal in the U.S. is certifiably not a genuine risk for a generally sound grown-up. In the event that you become ill, treat your side effects and contact a specialist in the event that they deteriorate [23] or do not leave. 


\section{GENOMIC ORGANIZATION}

CoVss contain a non-divided, positive-sense RNA genome of $\sim 30 \mathrm{~KB}$. The genome contains a $5^{\prime}$ top structure along with a $3^{\prime}$ poly (A) tail, permitting it to go about as a marina for interpretation of the replicase polyproteins. The replicas quality encoding the nonstructural proteins (naps) possesses $66 \%$ of the genome [24,28], around $20 \mathrm{~KB}$, instead of the basic and extra proteins, which make up just around $10 \mathrm{~KB}$ of the viral genome. The $5^{\prime}$ end of the genome contains a pioneer succession and untranslated locale (untranslated region [UTR]) that contains different stem circle structures required for RNA replication and translation [29]. Moreover, toward the start of each basic or frill quality is transcriptional administrative arrangements (TRSs) that are required for articulation of each of these qualities. The $3^{\prime}$ UTR too contains RNA structures required for replication and amalgamation of viral RNA [30,31]

The association of the coronavirus genome is $5^{\prime}$-pioneer UTR-replicas-S (Spike)- E (Envelope) - M (Membrane) - N (Nucleocapsid) - 3' UTRpoly (A) tail with embellishment qualities mixed inside the auxiliary qualities at the $3^{\prime}$ end of the genome [32].

The embellishment proteins are only superfluous for replication in tissue culture; in any case [33], some have been appearing to have significant jobs in viral pathogenesis.

\section{VIRION STRUCTURE}

$\mathrm{CoV}$ versions are round with measurements of roughly $125 \mathrm{NM}$ as portrayed in late examinations by cryo-electron tomography what is more, cryo-electron microscopy [34,35]. The most conspicuous component of CoVs is the club-formed spike projections exuding from the outside of the brain. These spikes are a definite highlight of the vision and give them the presence of a sunlight based crown, inciting the name, CoVs [36]. Inside the envelope of the brain is the nucleocapsid. CoVs have helically even nucleocapsids [37], which are extraordinary among positive-sense RNA infections [37], however unmistakably increasingly regular for negative-sense RNA infections [38]. The E protein $(\sim 8-$ $12 \mathrm{kDa}$ ) is found in little amounts in the brain. The coronavirus $\mathrm{E}$ proteins, however profoundly disparate, have a typical design [39]. The layer topology of E protein is not totally settled yet most information recommends that it is a transmembrane protein. The $\mathrm{E}$ protein has a $\mathrm{N}$-terminal ectodomain and a C-terminal endodomain and has particle channel action [40]. Rather than other basic proteins, recombinant infections coming up short on the E protein are not constantly deadly, despite the fact that this is an infection type subordinate [41,42]. The E protein encourages get together and arrival of the infection yet in addition has different capacities. In case, the particle direct action of SARS-CoV E protein is not required for viral replication, however, is required for pathogenesis [43].

The $\mathrm{N}$ protein establishes the main protein present in the nucleocapsid. It is made out of two separate areas, an N-terminal domain (NTD) and a C-terminal domains (CTD), both equipped for restricting RNA in vitro, yet every space utilizes extraordinary systems to tie RNA. It has been recommended that ideal RNA restricting requires commitments from the two areas $[45,46]$. N protein is likewise intensely phosphorylated [47], and phosphorylation has been proposed to trigger a basic change, upgrading the affinity for viral versus non-viral RNA. N protein ties the viral genome in a dabs on-a-string type compliance. Two specific RNA substrates have been identified Ed for N protein; the TRSs [48,49] what is more, the genomic bundling signal [50]. The genomic bundling signal has been found to tie specifically to the second or C-terminal RNA restricting area [51]. N protein likewise ties nsp3 [52,53], a key segment of the replicase complex, and the M protein [54]. This protein cooperation's likely assistance ties the viral genome to the replicastranscriptase complex, and along these lines bundle the encapsulated genome into viral particles. A I fetch auxiliary protein, the hem agglutinin-esterase, is present in a subset of $\beta$-CoVs. The protein goes about as a hem agglutinin, ties sialic acids on surface glycoprotein's, and contains acetyl-esterase movement [55]. These exercises are thought to upgrade S protein-intervened cell section and infection spread through the mucosa [56]. Curiously, HE upgrades murine hepatitis infection (MHV) neurovirulence [57]. In any case, it is chosen against in tissue culture for obscure reasons $[58,59]$.

\section{PATHOGENESIS}

\section{Human CoVs}

Preceding the SARS-CoV flare-up, CoVs were just idealistic to cause gentle, self-constraining respiratory diseases in people. Two of these human CoVs are $\alpha$-CoVs, $\mathrm{HCoV}-229 \mathrm{E}$ what is more, HCoV-NL63, while the other two are $\beta$-CoVs, HCoV-OC43, and HCoV-HKU1. HCoV-229E and HCoV-OC43 were separated about 50 years back [63,64], While HCoVNL63 and HCoV-HKU1 have as of late been identified following the SARS-CoV episode $[65,66]$. These infections are endemic in the human populaces, causing $15-30 \%$ of respiratory tract diseases every year. They cause increasingly serious illness in neonates, the older, also, in people with basic ailments, with a more prominent occurrence of the lower respiratory tract contamination in these populaces. HCoV-NL63 is additionally connected with intense laryngotracheitis (croup) [67]. One intriguing part of these infections is their disparities in resistance to hereditary changeability. $\mathrm{HCoV}-229 \mathrm{E}$ detaches from around the world have just insignificant succession disparity [80], while $\mathrm{HCoV}$ OC43 separates from a similar area yet detached in various years show signify cannot hereditary fluctuation [68]. This imaginable clarifies the failure of HCoV-229E to cross the species obstruction to taint mice while $\mathrm{HCoV}-\mathrm{OC} 43$ and the firm related ox-like coronavirus, $\mathrm{BCoV}$, are fit for tainting mice and a few ruminant animal groups. In light of the capacity of MHV to cause demyelinating ailment, It has been recommended that human cows might be engaged in the improvement of the various sclerosis (MS) [69]. Be that as it may, no proof to date proposes that human CoVs assume a signify cannot job in MS. SARS-CoV, A gathering $2 \mathrm{~b} \beta$-coronavirus, was identified as the causative operator of the SARS episode that happened in 2002-2003 in the Guangdong Province of China. It is the most serious human illness brought about by any CoV. During the 2002-2003 episode roughly 8098 cases happened with 774 passing's, bringing about a deathly pace of $9 \%$ Tables 1 and $2[70,71]$.

This rate was a lot higher in older people, with mortality rates, moving toward $50 \%$ in people more than 60 years old. Moreover, the episode brought about the loss of almost $\$ 40$ billion dollars in monetary movement, as the infection almost shut down numerous exercises in Southeast Asia and Toronto, Canada for a few months [72]. The episode started in an in Hong Kong and eventually spread to in excess of two dozen nations. During the plague, firmly related infections were disengaged from a few fascinating 5.2 Human CoVs Anthony R. Fehr and Stanley Perlman 13 creatures, including Himalayan palm civets and raccoon hounds [73]. In any case, it is broadly acknowledged that SARS-CoV began in bats as an enormous number of Chinese horseshoe bats contain groupings of SARS-related CoVs and contain serologic proof for an earlier disease with a related $\mathrm{CoV}[74,75]$. Indeed, two novel bat SARS related CoVs have been as of late identify Ed that is progressively like SARS-CoV than some other infection identify ad to date [76,77]. They were likewise found to utilize a similar receptor as the human infection, angiotensin changing over catalyst 2, giving additional proof that SARS$\mathrm{CoV}$ started in bats. Albeit some human people in wet creature markets had serologic proof of SARS-CoV contamination preceding the flare-up, these people had no obvious side effects [78]. Therefore, almost certainly, a firmly related infection circled in the wet creature markets for quite a while before a progression of elements encouraged its spread into the bigger populace. Transmission of SARS-CoV was generally inefficient, as it as it was, spread through direct contact with tainted people after the beginning of sickness. Along these lines, the episode was to a great extent contained in family units and medicinal services settings [79], aside from in a couple of instances of super spreading occasions where one individual had the option contaminate different contacts because of an improved advancement of high popular weights or capacity to aerosolize infection. Because of the moderately inefficient transmission 
of SARS-CoV, the episode was controllable using isolating. Just few SARS cases happened after the flare-up was controlled in June 2003. SARS$\mathrm{CoV}$ basically taints epithelial cells inside the lung. The infection is fit for entering macrophages and dendritic cells be that as it may, just prompts an unsuccessful disease $[80,81]$. Regardless of this, contamination of these cell types might be significant in initiating painful amatory cytokines that may add to malady. In reality, numerous cytokines and chemokines are created by these cell types and are raised in the serum of SARS-CoV tainted patients $[82,83]$. The specific component of lung damage and reason for serious infection in people stays dubious. Viral titers appear to decrease when extreme ailment creates in the two people and in a few creature models of the malady. Besides, creatures contaminated with rat adjusted SARS-CoV strains demonstrate comparative clinical highlights to the human ailment, including an age-subordinate increment in ailment seriousness [84]. These creatures additionally show expanded degrees of painful amatory cytokines and diminished T-cell reactions [85], proposing a conceivable immunopathological component of sickness $[86,87]$. While the SARS-CoV scourge was controlled in 2003 and the infection has not since restored, a novel human CoV rose in the Center East in 2012. This infection, named MERS-CoV, was seen as the causative specialist in a progression of profoundly pathogenic respiratory tract contaminations in Saudi Arabia and different nations in the Middle East [88,89]. In light of the high death pace of $\sim 50 \%$ in the beginning times of the flare-up, it $\mathrm{CoV}$ Introduction 14 was dreading the infection would prompt an intense flare-up. Be that as it may, the flare-up did not quicken in 2013, although sporadic cases proceeded all through the remainder of the year. In April 2014, a spike of more than 200 cases and just about 40 passings happened, provoking feelings of trepidation that the infection had transformed and was progressively equipped for human-to human transmission [90]. More probable, the expanded number of cases comes about because of improved location and detailing techniques joined by a regular increment in birthing camels. As of August 27, 2014, there have been an aggregate of 855 instances of MERS-CoV, with 333 passings and a case casualty pace of almost $40 \%$, as indicated by the European Center for Disease Prevention and Control. MERS-CoV is a gathering 2c $\beta$-coronavirus exceptionally identified with two beforehand identified CoVs, HKU4 and HKU5 [91,92]. It is accepted that the infection began from bats, however likely had an middle of the road have as people once in a while interact with bat secreta. Serological investigations have identified MERS-CoV antibodies in dromedary camels in the Middle East [93-95], and cell lines from camels have been seen as lenient for MERS-CoV replication $[96,97]$ giving proof that dromedary camels might be the common have. Additional persuading proof for this originates from late investigations recognizing almost indistinguishable MERS-curves in the two camels and human cases in close by vicinities in Saudi Arabia [98]. In one of these examinations, the human case had direct contact with a contaminated camel and the infection confined from this patient was indistinguishable from the infection confined from the camel [99]. Right now it remains to be resolved what number of MERS-CoV cases can be credited with a halfway host rather than human-to-human transmission. It has additionally been proposed that human-to-camel spread added to the flare-up. MERS-CoV uses Dipeptidyl peptidase 4 (DPP4) as its receptor [100]. The infection is just ready to utilize the receptor from certain species, for example, bats, people, camels, bunnies, and ponies to set up contamination. Lamentably for analysts, the infection is incapable to taint mouse cells because of contrasts in the structure of DPP4, making it difficult faction to assess potential immunizations or antivirals. As of late, a little creature model for MERS-CoV has been created utilizing an Adenoviral vector to present the human DPP4 quality into mouse lungs [101]. This one of a kind framework makes it conceivable to test restorative mediations and novel antibodies for MERS-curve in any creature delicately to adenoviral transductions.

\section{DETERMINATION, TREATMENT, AND PREVENTION}

By and large of self-constrained contamination, analysis of CoVs is pointless, as the illness will normally run its course. Be that as it may, it might be significant in certain clinical and veterinary settings or in epidemiological examinations to distinguish an etiological specialist. Analysis Anthony R. Fehr and Stanley Perlman 15 is likewise significant in areas where a serious $\mathrm{CoV}$ flare-up is happening, for example, at present, in the Middle East, where MERSCoV keeps on flowing. The identification of cases will manage the advancement of general well-being measures to control episodes. It is additionally imperative to analyze instances of serious veterinary CoV-induced sickness, for example, porcine epidemic diarrhea virus (PEDV) and infectious bronchitis virus (IBV), to control these pathogens and secure nourishment supplies. Reverse transcription polymerase chain reaction (RT-PCR) has become the strategy of decision for the determination of human CoV, As multiplex continuous RT-PCR examines have been created, can identify every one of the four respiratory HCoVs and could be additionally adjusted to novel CoVs [102,103]. Serologic examines are significant in situations where RNA is difficult religion to disengage or is never again present, and four epidemiological examines. Until this point in time, there are no antiviral therapeutics that specifically target human CoVs, so medications are just strong. In vitro, interferons (IFNs) are just somewhat successful against CoVs [104]. IFNs in the mix with ribavirin may have expanded movement in vitro when contrasted with IFNs alone against some CoVs; nonetheless, the viability of this mix in five requires further assessment [105]. The SARS and MERS episodes have invigorated research on these infections and this explore has identified countless appropriate antiviral targets, for example, viral proteases, polymerases, and section proteins. Signify cannot work remains, be that as it may, to create drugs that focus on these procedures furthermore, can repress viral replication. Just constrained choices are accessible to forestall carnivorous diseases. Immunizations have just been endorsed for IBV, transmissible gastroenteritis virus (TGEV), and Canine $\mathrm{CoV}$, however, these immunizations are not constantly utilized in light of the fact that they are either not extremely powerful, or now and again have been accounted for to be associated with the determination of novel pathogenic curves by means of recombination of flowing strains. Antibodies to veterinary pathogens, for example, PEDV, might be valuable in such situations where the spread of the infection to another area could prompt serious misfortunes of veterinary creatures. On account of SARS-CoV, few potential antibodies have been grown yet none is yet endorsed for use. These immunizations incorporate recombinant constricted infections, live infection vectors, or individual viral proteins communicated from DNA plasmids. Helpful SARS-CoV killing antibodies have been created and could be recovered and utilized again in case of another SARS-CoV flare-up. Such antibodies would be generally valuable for ensuring human services laborers. When all is said in done, it is imagined that live lessened antibodies would be the most efficacious in focusing on CoVs. This was outlined on account of TGEV, where a constricted variation, porcine respiratory coronavirus (PRCV), showed up in Europe during the 1980s. This variation just caused gentle infection and totally shielded swine from TGEV. Along these lines, this constricted infection has normally forestalled the occurrence of extreme TGEV in Europe and the U.S. in the course of recent years [106]. In spite of this achievement, antibody improvement for CoVs faces CoV introduction 16 numerous difficulties [107]. Initially, for mucosal contaminations, characteristic disease does not forestall consequent contamination, thus antibodies should either initiate preferred invulnerability over the first infection or should at any rate decrease the sickness caused during an optional contamination. Second, the inclination of the infections to recombine may represent an issue by rendering the antibody pointless and conceivably expanding the advancement and assorted variety of the infection in the wild [108]. At last, it has been appearing in feline infectious peritonitis virus that inoculation with S protein prompts to upgrade illness [109]. Regardless of this, few procedures are being created for immunization improvement to decrease the probability of recombination, for example, by making enormous erasures in the nsp1 or E proteins [110-111], modifying the $3^{\prime}$ end of the genome [112], altering the TRS arrangements, or utilizing freak infections with unusually high transformation rates that signify weaken the infection. Inferable from the absence of compelling therapeutics or immunizations, the best measures to control human CoVs stay a solid open well-being reconnaissance framework combined with quick indicative testing furthermore, isolate when fundamental. For universal episodes, participation of administrative elements, 


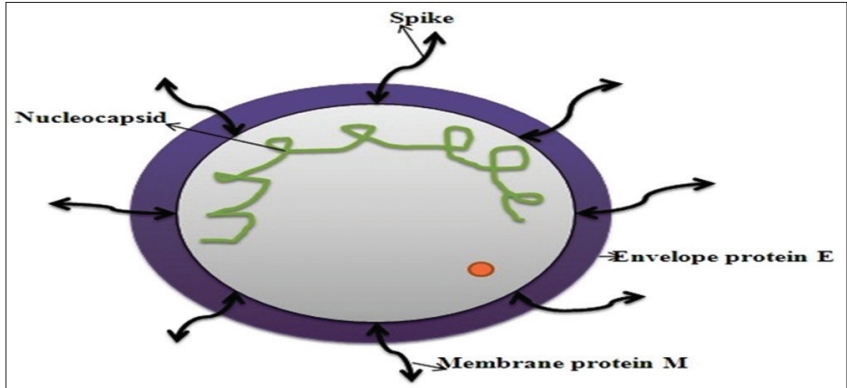

Fig. 1: Coronaviruses [6,7]

Table 1: The ordered structure of the family [8-10]

\begin{tabular}{ll}
\hline Family & Coronaviridae \\
Subfamily & Coronavirinae \\
Genus & Alphacoronavirus \\
Genus & Betacoronavirus \\
Genus & Gammacoronavirus \\
Subfamily & Torovirinae \\
Genus & Torovirus \\
Genus & Bafinivirus \\
\hline
\end{tabular}

Table 2: Coronavirus receptors [60-62]

\begin{tabular}{ll}
\hline Virus & Receptor \\
\hline HCoV -229E & Aminopeptidase N \\
HCoV -NL63 & Angiotensin-converting enzyme 2 \\
TGEV & Aminopeptidase N \\
PEDV & Aminopeptidase N \\
FIPV & Aminopeptidase N \\
CCoV & Aminopeptidase N \\
MHV & m CEACAM \\
Bovine coronavirus & N-acetyl-9- O-acetylneuraminic acid \\
SARS-CoV & ACE2 \\
MERS-CoV & DPP4 \\
\hline
\end{tabular}

HCoV: Human coronavirus, TGEV: Transmissible gastroenteritis virus, PEDV: Porcine epidemic diarrhea virus, FIPV: Feline infectious peritonitis virus, CCoV: Canine coronavirus, MHV: Murine hepatitis virus, SARSCoV: Severe acute respiratory syndrome coronavirus, MERS-CoV: Middle east respiratory syndrome coronavirus, ACE2: Angiotensin changing over catalyst 2 , DPP4: Dipeptidyl peptidase 4

general well-being specialists, and medicinal services suppliers are basic [113]. During veterinary flare-ups that are promptly transmitted, for example, PEDV, progressively intense estimates such as decimation of whole groups of pigs might be important to forestall transmission of these destructive infections.

\section{ACKNOWLEDGMENT}

The authors sincerely thank Gurunanak Institute of Technical Campus School of pharmacy, Hyderabad, Telangana, India, for contributing to this study.

\section{CONTRIBUTION OF AUTHORS}

1. Sagara Pamu: Compiled the literature sources, data analysis, and interpretation, wrote the manuscript

2. Kosika Sandeep, Chindam Suresh: Helped in data interpretation, the concept of work, and its realization and manuscript evaluation.

\section{CONFLICTS OF INTEREST}

Nothing to declare.

\section{AUTHORS FUNDING}

No funding source from any organizations.

\section{REFERENCES}

1. Chen Y, Cai H, Pan J, Xiang N, Tien P, Ahola T, et al. Functional screen reveals SARS coronavirus nonstructural protein nsp14 as a novel cap N7 methyltransferase. Proc Natl Acad Sci U S A 2009;106:3484-9.

2. Barcena M, Oostergetel GT, Bartelink W. Cryo-electron tomography of mouse hepatitis virus: Insights into the structure of the coronavirion. Proc Natl Acad Sci U S A 2009;106:582-7.

3. Neuman BW, Adair BD, Yoshioka C, Quispe JD, Orca G, Kuhn P, et al. Supramolecular architecture of severe acute respiratory syndrome coronavirus revealed by electron cryomicroscopy. J Virol 2006;80:7918-28.

4. Godet M, Haridon R, Vautherot JF, Laude H. TGEV corona virus ORF4 encodes a membrane protein that is incorporated into virions. Virology 1992;188:666-75.

5. DeDiego ML, Alvarez E, Almazan F, Rejas MT, Lamirande E, Roberts A, et al. A severe acute respiratory syndrome coronavirus that lacks the $\mathrm{E}$ gene is attenuated in vitro and in vivo. J Virol 2007;81:1701-13.

6. Chang CK, Sue SC, Yu TH, Hsieh CM, Tsai CK, Chiang YC, et al. Modular organization of SARS coronavirus coronavirus introduction 18 nucleocapsid protein. J Biomed Sci 2006;13:59-72.

7. Hurst KR, Koetzner CA, Masters PS identification of in vivointeracting domains of the murine coronavirus nucleocapsid protein. J Virol 2009;83:7221-34.

8. Stohlman SA, Baric RS, Nelson GN, Soe LH, Welter LM, Deans RJ. Specific interaction between coronavirus leader RNA and nucleocapsid protein. J Virol 1988;62:4288-95.

9. Molenkamp R, Spaan WJ. Identification of a specific interaction between the coronavirus mouse hepatitis virus A59 nucleocapsid protein and packaging signal. Virology 1997;239:78-86.

10. Kuo L, Masters PS. Functional analysis of the murine coronavirus genomic RNA packaging signal. J Virol 2013;87:5182-92.

11. Hurst KR, Koetzner CA, Masters PS. Characterization of a critical interaction between the coronavirus nucleocapsid protein and nonstructural protein 3 of the viral replicase transcriptase complex. J Virol 2013;87:9159-72.

12. Sturman LS, Holmes KV, Behnke J. Isolation of coronavirus envelope glycoproteins and interaction with the viral nucleocapsid. J Virol 1980;33:449-62.

13. Klausegger A, Strobl B, Regl G, Kaser A, Luytjes W, Vlasak R, et al. Identification of a coronavirus hemagglutinin esterase with a substrate specifi city different from those of influenza $\mathrm{C}$ virus and bovine coronavirus. J Virol 1999;73:3737-43.

14. Cornelissen LA, Wierda CM, van der Meer FJ, Herrewegh AA, Horzinek MC, Egberink HF, et al. Hemagglutinin-esterase, a novel structural protein of torovirus. J Virol 1997;71:5277-86.

15. Kazi L, Lissenberg A, Watson R, Groot RJ, Weiss SR. Expression of hemagglutinin esterase protein from recombinant mouse hepatitis virus enhances neurovirulence. J Virol 2005;79:15064-73.

16. Lissenberg A, Vrolijk MM, van Vliet AL, Langereis MA, de Groot-Mijnes JD, Rottier PJ, et al. Luxury at a cost recombinant mouse hepatitis viruses expressing the accessory hemagglutinin esterase protein display reduced fitness in vitro. J Virol 2005;79:15054-63.

17. Cheng PK, Wong DA, Tong LK, Lau CS, Yeung EY, Lim WW, et al. Viral shedding patterns of coronavirus in patients with probable severe acute respiratory syndrome. Lancet 2004;363:1699-700.

18. Belouzard S, Chu VC, Whittaker GR. Activation of the SARS coronavirus spike protein via sequential proteolytic cleavage at two distinct sites. Proc Natl Acad Sci U S A 2009;106:5871-6.

19. Baranov PV, Henderson CM, Anderson CB, Gesteland RF, Atkins JF, Howard MT, et al. Programmed ribosomal frame shifting in decoding the SARS-CoV genome. Virology 2005;332:498-510.

20. Brierley I, Digard P, Inglis SC. Characterization of an efficient coronavirus ribosomal frame shifting signal: Requirement for an RNA pseudoknot. Cell 1989;57:537-47.

21. Araki K, Gangappa S, Dillehay DL, Rouse BT, Larsen CP, Ahmed R. Pathogenic virus-specifi c T cells cause disease during treatment with the calcineurin inhibitor FK506: Implications for transplantation. J Exp Med 2010;207:2355-67.

22. Ziebuhr J, Snijder EJ, Gorbalenya AE. Virus-encoded proteinases and proteolytic processing in the Nidovirales. J Gen Virol 2000;81:853-79.

23. Snijder EJ, Bredenbeek PJ, Dobbe JC, Thiel V, Ziebuhr J, Poon LL, et al. Unique and conserved features of genome and proteome of SARS-coronavirus, an early split-off from the coronavirus group 2 lineage. J Mol Biol 2003;331:991-1004.

24. Sethna PB, Hofmann MA, Brian DA. Minus-strand copies of replicating coronavirus mRNAs contain antileaders. J Virol 
1991;65:320-5.

25. Brown CG, Nixon KS, Senanayake SD. An RNA stem-loop within the bovine coronavirus nsp1 coding region is a cis-acting element in defective interfering RNA replication. J Virol 2007;81:7716-24.

26. Guan BJ, Wu HY, Brian DA. An optimal cis-replication stem-loop IV in the 5 ' untranslated region of the mouse coronavirus genome extends 16 nucleotides into open reading frame 1. J Virol 2011;85:5593-605.

27. Liu P, Li L, Keane SC. Mouse hepatitis virus stem-loop 2 adopts a uYNMG(U)a-like tetraloop structure that is highly functionally tolerant of base substitutions. J Virol 2009;83:12084-93.

28. Raman S, Bouma P, Williams GD, Brian DA. Stem-loop III in the 5 ' untranslated region is a cis-acting element in bovine coronavirus defective interfering RNA replication. J Virol 2003;77:6720-30.

29. Liu Q, Johnson RF, Leibowitz JL. Secondary structural elements within the 3' untranslated region of mouse hepatitis virus strain JHM genomic RNA. J Virol 2001;75:12105-13.

30. Goebel SJ, Miller TB, Bennett CJ, Bernard KA, Masters PS. A hypervariable region within the 3' cis- acting element of the murine coronavirus genome is nonessential for RNA synthesis but affects pathogenesis. J Virol 2007;81:1274-87.

31. Williams GD, Chang RY, Brian DA. A phylogenetically conserved hairpin-type 3' untranslated region pseudoknot functions in coronavirus RNA replication. J Virol 1999;73:8349-55.

32. Hsue B, Masters PS. A bulged stemloop structure in the 3' untranslated region of the genome of the coronavirus mouse hepatitis virus is essential for replication. J Virol 1997;71:7567-78.

33. Hsue B, Hartshorne T, Masters PS. Characterization of an essential RNA secondary structure in the 3' untranslated region of the murine coronavirus genome. J Virol 2000;74:6911-21.

34. Sawicki SG, Sawicki DL, Siddell SG. Contemporary view of coronavirus transcription. J Virol 2007;81:20-9.

35. Bentley K, Keep SM, Armesto M, Britton P. Identification of a noncanonically transcribed subgenomic mRNA of infectious bronchitis virus and other gammacoronaviruses. J Virol 2013;87:2128-36.

36. Keck JG, Makino S, Soe LH, Fleming JO, Stohlman SA, Lai MM. RNA recombination of coronavirus. Adv Exp Med Biol 1987;218:99-107.

37. Lai MM, Baric RS, Makino S, Keck JG, Egbert J, Leibowitz JL. Recombination between nonsegmented RNA genomes of murine coronaviruses. J Virol 1985;56:449-56.

38. Krijnse-Locker J, Ericsson M, Rottier PJ, Griffiths G. Characterization of the budding compartment of mouse hepatitis virus: Evidence that transport from the RER to the Golgi complex requires only one vesicular transport step. J Cell Biol 1994;124:55-70.

39. Tooze J, Tooze S, Warren G. Replication of coronavirus MHV-A59 in saccells: Determination of the first site of budding of progeny virions. Eur J Cell Biol 1984;33:281-93.

40. de Haan CA, Rottier PJ. Molecular interactions in the assembly of coronaviruses. Adv Virus Res 2005;64:165-230.

41. Bos EC, Luytjes W, van der Meulen HV, Koerten HK, J Spaan WJ. The production of recombinant infectious DI-particles of a murine coronavirus in the absence of helper virus. Virology 1996;218:52-60.

42. Siu YL, Teoh KT, Lo J, Chan CM, Kien F, Escriou N, et al. The M, E, and $\mathrm{N}$ structural proteins of the severe acute respiratory syndrome coronavirus are required for efficient assembly, trafficking, and release of virus-like particles. J Virol 2008;82:11318-30

43. Raamsman MJ, Locker JK, de Hooge A, Griffiths G, Vennema H, Rottier PJ. Characterization of the coronavirus mouse hepatitis virus strain A59 small membrane protein E. J Virol 2000;74:2333-42.

44. Corse $\mathrm{E}$, Machamer $\mathrm{CE}$ Infectious bronchitis virus $\mathrm{E}$ protein is targeted to the Golgi complex and directs release of virus-like particles. J Virol 2000;74:4319-26

45. Fischer F, Stegen CF, Masters PS, Samsonoff WA. Analysis of constructed $\mathrm{E}$ gene mutants of mouse hepatitis virus confirms a pivotal role for E protein in coronavirus assembly. J Virol 1998;72:7885-94.

46. Boscarino JA, Logan HL, Lacny JJ, Gallagher TM. Envelope protein palmitoylations are crucial for murine coronavirus assembly. J Virol 2008;82:2989-99.

47. Ye Y, Hogue BG. Role of the coronavirus E viroporin protein transmembrane domain in virus assembly. J Virol 2007:81:3597-607.

48. Hurst KR, Kuo L, Koetzner CA, Ye R, Hsue B, Masters PS. A major determinant for membrane protein interaction localizes to the carboxyterminal domain of the mouse coronavirus nucleocapsid protein. J Virol 2005;79:13285-97.

49. Perlman S, Netland J. Coronaviruses post-SARS: Update on replication and pathogenesis. Nat Rev Microbiol 2009;7:439-50.

50. Mihindukulasuriya KA, Wu G, Leger J, Nordhausen RW, Wang D. Identification of a novel coronavirus from a beluga whale by using a panviral microarray. J Virol 2008;82:5084-8

51. He B, Zhang Y, Xu L, Yang W, Feng Y, Xia L, et al. Identification of diverse alphacoronaviruses Coronavirus Introduction 20 and genomic characterization of a novel severe acute respiratory syndrome-like coronavirus from bats in china. J Virol 2014;88:7070-82.

52. Lauber C, Ziebuhr J, Junglen S, Drosten C, Zirkel F, Thi Nga P, et al. Mesoniviridae: A proposed new family in the order nidovirales formed by a single species of mosquito-borne viruses. Arch Virol 2012;157:1623-8.

53. Levy GA, Liu M, Ding J, Yuwaraj S, Leibowitz J, Marsden PA, et al. Molecular and functional analysis of the human prothrombinase gene (HFGL2) and its role in viral hepatitis. Am J Pathol 2000;156:1217-25.

54. Lampert PW, Sims JK, Kniazeff AJ. Mechanism of demyelination in JHM virus encephalomyelitis. Acta Neuropathol 1973;24:76-85.

55. Weiner LP. Pathogenesis of demyelination induced by a mouse hepatitis virus (JHM virus). Arch Neurol 1973;28:298-303.

56. Wu GF, Dandekar AA, Pewe L, Perlman S. CD4 and CD8 T cells have redundant but not identical roles in virus-induced demyelination. J Immunol 2000;165:2278-86

57. Wang F, Stohlman SA, Fleming JO. Demyelination induced by murine hepatitis virus JHM strain (MHV-4) is immunologically mediated. J Neuroimmunol 1990;30:31-41.

58. Wu GF, Perlman S. Macrophage infiltration, but not apoptosis, is correlated with immune-mediated demyelination following murine infection with a neurotropic coronavirus. J Virol 1999;73:8771-80.

59. McIntosh K, Becker WB, Chanock RM. Growth in suckling-mouse brain of "IBV-like" viruses from patients with upper respiratory tract disease. Proc Natl Acad Sci USA 1967;58:2268-73.

60. Bradburne AF, Bynoe ML, Tyrell DA. Effects of a "new" human respiratory virus in volunteers. Br Med J 1967;3:767-9.

61. Hamre D, Procknow JJ. A new virus isolated from the human respiratory tract. Proc Soc Exp Biol Med 1996;121:190-3.

62. Woo PC, Lau SK, Chu CM, Chan KH, Tsoi HW, Huang Y, et al. Characterization and complete genome sequence of a novel coronavirus, coronavirus HKU1, from patients with pneumonia. J Virol 2005;79:884-95.

63. van der Hoek L, Pyrc K, Jebbink MF, Vermeulen-Oost W, Berkhout R, Wolthers $\mathrm{KC}$, et al. Identification of a new human coronavirus. Nat Med 2004;10:368-73.

64. Chibo D, Birch C. Analysis of human coronavirus 229E spike and nucleoprotein genes demonstrates genetic drift between chronologically distinct strains. J Gen Virol 2006;87:1203-8.

65. Vijgen L, Keyaerts E, Lemey P, Moës E, Li S, Vandamme AM, et al. Circulation of genetically distinct contemporary human coronavirus OC43 strains. Virology 2005;337:85-92.

66. Guan Y, Zheng BJ, He YQ, Liu XL, Zhuang ZX, Cheung CL, et al. Isolation and characterization of viruses related to the SARS coronavirus from animals in Southern China. Science 2003;302:276-8

67. Lau SK, Woo PC, Li KS, Huang Y, Tsoi HW, Wong HL, et al. Severe acute respiratory syndrome coronavirus-like virus in Chinese horseshoe bats. Proc Natl Acad Sci U S A 2005; 102:14040-5.

68. Li W, Shi Z, Yu M, Ren W, Smith C, Epstein JH, et al. Bats are natural reservoirs of SARS-like coronaviruses. Science 2005;310:676-9.

69. Ge XY, Li JL, Yang XL, Chmura AA, Zhu G, Epstein JH, et al. Isolation and characterization of a bat SARS-like coronavirus that uses the ACE2 receptor. Nature 2013;503:535-8.

70. Peiris JS, Yuen KY, Osterhaus AD, Stöhr K. The severe acute respiratory syndrome. N Engl J Med 2003;349:2431-41.

71. Peiris JS, Chu CM, Cheng VC, Chan KS, Hung IF, Poon LL, et al. Clinical progression and viral load in a community outbreak of coronavirus-associated SARS pneumonia: A prospective study. Lancet 2003;361:1767-72.

72. Spiegel M, Schneider K, Weber F, Weidmann M, Hufert FT. Interaction of severe acute respiratory syndrome- associated coronavirus with dendritic cells. J Gen Virol 2006;87:1953-60.

73. Law HK, Cheung CY, Ng HY, Sia SF, Chan YO, Luk YO, et al. Chemokine upregulation in SARS coronavirus infected human monocyte derived dendritic cells. Blood 2005;106:2366-76.

74. Lau YL, Peiris JS. Pathogenesis of severe acute respiratory syndrome. Curr Opin Immunol 2005;17:404-10.

75. Roberts A, Paddock C, Vogel L, Butler E, Zaki S, Subbarao K. Aged $\mathrm{BALB} / \mathrm{c}$ mice as a model for increased severity of severe acute respiratory syndrome in elderly humans. J Virol 2005;79:5833-8.

76. Zhao J, Zhao J, Perlman S. T cell responses are required for protection from clinical disease and for virus clearance in severe acute respiratory syndrome coronavirusinfected mice. J Virol 2010;84:9318-25.

77. Zhao J, Legge K, Legge K, Perlman S. Agerelated increases in PGD(2) 
expression impair respiratory DC migration, resulting in dimin Anthony R. Fehr and Stanley Perlman 21 ished T cell responses upon respiratory virus infection in mice. J Clin Invest 2011;121:4921-30.

78. Zaki AM, van Boheemen S, Bestebroer TM, Osterhaus DM, Fouchier AM, et al. Isolation of a novel coronavirus from a man with pneumonia in Saudi Arabia. N Engl J Med 2012;367:1814-20.

79. Meyer B, Muller MA, Corman VM, Reusken BE, Ritz D, Godeke GJ, et al. Antibodies against MERS coronavirus in dromedary camels, United Arab Emirates, 2003 and 2013. Emerg Infect Dis 2014;20:552-9.

80. Eckerle I, Corman VM, Muller MA, Lenk M, Ulrich RG, Drosten C. Replicative capacity of MERS coronavirus in livestock cell lines. Emerg Infect Dis 2014;20:276-9.

81. Memish ZA, Cotten M, Meyer B, Watson SJ, Alsahafi AJ, Al Rabeeah A, et al. Human infection with MERS coronavirus after exposure to infected camels, Saudi Arabia, 2013. Emerg Infect Dis 2014;20:1012-15.

82. Raj VS, Mou H, Smits SL, Dekkers DH, Müller, MA, Dijkman R, et al. Dipeptidyl peptidase 4 is a functional receptor for the emerging human coronavirus EMC. Nature 2013;495:251-4.

83. Zhao J, Li K, Wohlford-Lenane C, Agnihothram SS, Fett C, Zhao J, et al. Rapid generation of a mouse model for Middle East respiratory syndrome. Proc Natl Acad Sci USA 2014;111:4970-5.

84. Emery SL, Erdman DD, Bowen MD, Newton BR, Winchell JM, et al. Real-time reverse transcriptionpolymerase chain reaction assay for SARS associated coronavirus. Emerg Infect Dis 2004;10:311-6.

85. Gaunt ER, Hardie A, Claas EC, Simmonds P, Templeton KE. Epidemiology and clinical presentations of the four human coronaviruses 229E, HKU1, NL63, and OC43 detected over 3 years using a novel multiplex real-time PCR method. J Clin Microbiol 2010;48:2940-7.

86. Cinatl J, Morgenstern B, Bauer G, Chandra P, Rabenau H, Doerr HW. Treatment of SARS with human interferons. Lancet 2003;362:293-4.

87. Laude H, Van Reeth K, Pensaert M. Porcine respiratory coronavirus: Molecular features and virus-host interactions. Vet Res 1993;24:125-50.

88. Saif LJ. Animal coronavirus vaccines: Lessons for SARS. Dev Biol (Basel) 2004;119:129-40.

89. Wang L, Junker D, Collisson EW. Evidence of natural recombination within the S1 gene of infectious bronchitis virus. Virology 1993;192:710-6.

90. Vennema H, de Groot RJ, Harbour DA, Dalderup M, Gruffydd-Jones T, Horzinek MC, et al. Early death after feline infectious peritonitis virus challenge due to recombinant vaccinia virus immunization. J Virol 1990;64:1407-9.

91. Netland J, DeDiego ML, Zhao J, Fett C, Álvarez E, Nieto-Torres JL, et al. Immunization with an attenuated severe acute respiratory syndrome coronavirus deleted in $\mathrm{E}$ protein protects against lethal respiratory disease. Virology 2010;399:120-8.

92. de Haan CA, Volders H, Koetzner CA, Masters PS, Rottier PJ. Coronaviruses maintain viability despite dramatic rearrangements of the strictly conserved genome organization. J Virol 2002;76:12491-502.

93. Yount B, Roberts RS, Lindesmith L, Baric RS. Rewiring the severe acute respiratory syndrome coronavirus (SARS-CoV) transcription circuit: Engineering a recombinationresistant genome. Proc Natl Acad Sci U S A 2006;103:12546-51.

94. Graham RL, Becker MM, Eckerle LD, Bolles M, Denison MR, Baric RS. A live, impaired-fi delity coronavirus vaccine protects in an aged, immunocompromised mouse model of lethal disease. Nat Med 2012;18:1820-6

95. Yeager CL, Ashmun RA, Williams RK, Cardellichio CB, Shapiro LH, Look AT, et al. Human aminopeptidase $\mathrm{N}$ is a receptor for human coronavirus 229E. Nature 1992;357:420-2.

96. Hofmann H, Pyrc K, van der Hoek L, Geier M, Berkhout B,
Pöhlmann S. Human coronavirus NL63 employs the severe acute respiratory syndrome coronavirus receptor for cellular entry. Proc Natl Acad Sci U S A 2005;102:7988-93.

97. Delmas B, Gelfi J, L'Haridon R, Vogel LK, Sjöström H, Norén O, et al. Aminopeptidase $\mathrm{N}$ is a major receptor for the coronavirus introduction 22 entero-pathogenic coronavirus TGEV. Nature 1992;357:417-20.

98. Li BX, Ge JW, Li YJ. Porcine aminopeptidase $\mathrm{N}$ is a functional receptor for the PEDV coronavirus. Virology 2007;365:166-72.

99. Tresnan DB, Levis R, Holmes KV. Feline aminopeptidase N serves as a receptor for feline, canine, porcine, and human coronaviruses in serogroup I. J Virol 1996;70:8669-74.

100. Benbacer L, Kut E, Besnardeau L, Laude H, Delmas B. Interspecies aminopeptidase- $\mathrm{N}$ chimeras reveal species-specifi c receptor recognition by canine coronavirus, feline infectious peritonitis virus, and transmissible gastroenteritis virus. J Virol 1997;71:734-7.

101. Nedellec P, Dveksler GS, Daniels E, Turbide C, Chow B, Basile AA, et al. Bgp2, a new member of the carcinoembryonic antigen-related gene family, encodes an alternative receptor for mouse hepatitis viruses. J Virol 1994;68:4525-37.

102. Williams RK, Jiang GS, Holmes KV. Receptor for mouse hepatitis virus is a member of the carcinoembryonic antigen family of glycoproteins. Proc Natl Acad Sci U S A 1991;88:5533-6.

103. Schultze B, Herrler G. Bovine coronavirus uses N-acetyl-9-Oacetylneuraminic acid as a receptor determinant to initiate the infection of cultured cells. J Gen Virol 1992;73(Pt 4):901-6.

104. Li W, Moore MJ, Vasilieva N, Sui J, Wong SK, Berne MA, et al. Angiotensin-converting enzyme 2 is a functional receptor for the SARS coronavirus. Nature 2003;426:450-4.

105. Huang C, Lokugamage KG, Rozovics JM, Narayanan K, Semler BL, Makino S. Alphacoronavirus transmissible gastroenteritis virus nsp1 protein suppresses protein translation in mammalian cells and in cellfree HeLa cell extracts but not in rabbit reticulocyte lysate. J Virol 2011;85:638-43.

106. Kamitani W, Huang C, Narayanan K, Lokugamage KG, MakinoS. A two-pronged strategy to suppress host protein synthesis by SARS coronavirus Nsp1 protein. Nat Struct Mol Biol 2009;16:1134-40.

107. Kamitani W, Narayanan K, Huang C, Lokugamage K, Ikegami T, Ito $\mathrm{N}$, et al. Severe acute respiratory syndrome coronavirus nsp1 protein suppresses host gene expression by promoting host mRNA degradation. Proc Natl Acad Sci U S A 2006;103:12885-90.

108. Tanaka T, Kamitani W, DeDiego ML, Enjuanes L, Matsuura Y. Severe acute respiratory syndrome coronavirus nspl facilitates efficient propagation in cells through a specifi c translational shutoff of host mRNA. J Virol 2012;86:11128-37.

109. Graham RL, Sims AC, Brockway SM, Baric RS, Denison MR. The nsp2 replicase proteins of murine hepatitis virus and severe acute respiratory syndrome coronavirus are dispensable for viral replication. J Virol 2005;79:13399-411.

110. Cornillez-Ty CT, Liao L, Yates JR $3^{\text {rd }}$, Kuhn K, Buchmeier MJ. Severe acute respiratory syndrome coronavirus nonstructural protein 2 interacts with a host protein complex involved in mitochondrial biogenesis and intracellular signaling. J Virol 2009;83:10314-8.

111. Chatterjee A, Johnson MA, Serrano P, Pedrini B, Joseph JS, Neuman W, et al. Nuclear magnetic resonance structure shows that the severe acute respiratory syndrome coronavirus-unique domain contains a macrodomain fold. J Virol 2009;83:1823-36.

112. Egloff MP, Malet H, Putics A, Heinonen M, Dutartre H, Frangeul A, et al. Structural and functional basis for ADPribose and poly (ADPribose) binding by viral macro domains. J Virol 2006;80:8493-502.

113. Eriksson KK, Cervantes-Barragan L, Ludewig B, Ludewig B, Thiel V. Mouse hepatitis virus liver pathology is dependent on ADPribose-1"- phosphatase, a viral function conserved in the alpha-like supergroup. J Virol 2008;82:12325-34. 